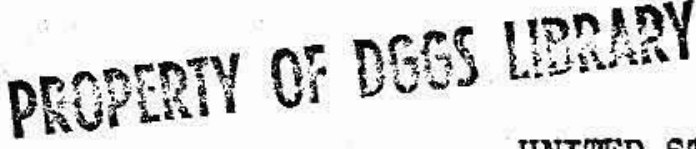 \\ UNITED STATES \\ DEPARTMENT OF THE INTERICR \\ Geological survey \\ Wastington.
}

42743

THE ZINC DEPOSXIS OF THE IUCKY BOY CHATMS, DORA IAKE, PRINEE OF WALES ISIAND, SOUMHEASTERN AIASKA

By

W. S. Twenhofel:

Introduotion

The Iucky Boy group of eight claims is along the southeastern and southern edges of Dora lake, a small lake about one-quarter of a mile south of the head of Dora Bay, a small flord extending south from Cholmondeley Sound on the east coast of Prince of Wales Island, southeastern Alaska. The claims are best reached from the head of Dora Bay by a good trail to the lower end of Dora Iake (alt. \pm 60 feet) and thence across the lake by skiff to the upper end (see fig. I).

I. C. Snith, S. V. Van Zandt, W. H. Roselle, and Clara Rung, all of Ketehikan, Alaska are said to have lacated the claims about 1933 or 1934 . Previous to that time the property is reported to have been claimed by Jack Westlake and to have been known as the Complex group of claims. Apparently the Iucky Bay clajms include most if not $a .11$ of the Iady of the Iake claims and the Oregon and Idaho clacins mentioned by the Wrights $1 /$."

Geology of the deposits

According to the Wrights $1 / 2$

"in. limestone and sohist constitute the prinoipal bedrock exposures within this anea, and an the west side of the bay these are intruded iy a wide area of granito, which 'also forms the west shore of Dora Iake."

The mineral deposits are quartz-calcite breccia veins that cut across the banding in the sohtst. The principal sulfide minerals are sphalerite, galena, chalcow pyri,te and pymite. Only locally do the sulfide minenals exceed about 10 percent of the total vein material and at most places the percent of sulfide minerals is estimated to be about 5. Numerous partially repleced schist and limestone fragments occur, within the veins.

The Iucky Boy elaims cover two general areas of mineralization; one about 750 feet south of the southern end of Dora Lake and the other along the east shore of the lake about 1200 feet from Dora Iake (see flg. 1).

\section{South roup of veins}

The south deposit is that mentioned by the Wrights $1 /$ as within the oregon and

I/ Wright, F. E. and C.W., the Ketchikan and Wrangell mining districts, Alaska: U.S. Geol. Survey Bul1. 347, pp. I71-1.72, 1908. 
Idaho clains. The deposit is a quarta-calcite vein that strikes about $\mathrm{N} .22^{\circ} \mathrm{E}$ and dips about $35^{\circ} \mathrm{E}$. The surface cuts oxpose the vein for about 380 feet approximately along the 125 foot.contcur of the east slope of the north-south valley that extends from Dora Iake to Mineral lake. Underground openings expose the vein for a strike distance of about 110 feet and for a dip length of about 60 feet. On the surface the vein is persistant and carries a relatively large emount of sphalerite. How ever, the vein as exposed underground is discontinous and except on the nor th end of the crosscut there is only slight sphalerite mineralization. The inclined raise that extends from near the face of the adit to near the surface is only slightly mineralized except near the surface where the sphalerite content increases gradually toward the surface.

A chip sample taken across the vein at the northermost pit contained 8.82 percent of zinc, and only minor amounts of lead, copper, gold and silver. These two samples represent material that is estimated to be the richest in tho vein. The vein exposed underground is estimated to carry one-third or even one-quarter the amount of sphalerite that the samples indicate the vein carries in the surface cuts.

Fon punposes of estimating reserves it is assumed that the nineralized zone is 380 feet long, 2 feet wide and extends down the dip for about 20 feet. A figure of 20 feet is used because the vein as exposed in the raje and in the crosscut does not appear to be persistent or well mineralized at depth. Because the two chip samples were taken from some of the richest parts of the veln, it is assumed that the average grade is considerably lower than the analyses would indioate; probably about 3 percent of zinc. It is esitimated that about 1500 tons of 3 -percent $z$ inc are indicated in this deposit. No inferred tonnage kas been estimated because the deposit is definitely limited in depth as shown by the nearly barren underground workings. If a larger tonnage is present. it w1Il probably be found by exposing the vein for a greater distance on the starface.

\section{The north group of vieins:}

The north area of minexulization inoludes at least three velns. All of them are quarti-calcite breccia voins slightly mineralized with sphalerite, galena, pyrite, and chalcopyrite.

A vein, I feet thick that is partially exposed at the beach a long the east * shore of Doir Iake and in twio pits for a distance of 160 feet, strikes about N. $10^{\circ}$ W. and dips about $70^{\circ} \mathrm{W}$. A chip sample taken across the vein at the beach contained 3.80 percent of 2 ine and 0.36 percent of lead.

Two other veins (see fig. 3) crop out at an elevation of about 330 feet on the east side of Dora Lake about 400 feet southeast of the vein on the beach. The most noriherly of the two veins strikes about $\mathrm{N}_{0} 35^{\circ} \mathrm{W}$, and dips about $70^{\circ} \mathrm{SW}$. It averages about 7 feet thick and is partially exposed for a length of 150 feet. The other vein strikes about north and dips about $80^{6} \mathrm{~W}$. It is about 20 feet thick on the surface and 5 feet wide exposed in the 65 -foot adit. It is exposed for a length of 85 feet and crops out over a vertical distance of 80 feet. 
One sample was selected from a small ore pile near the most northerly of the two veins. It contained 5.23 percent of zinc, 2.05 percent of lead and minor amounts of gold and silver, The sample was selected as the average of the better grade material and the entire vein undoubtedly averages much less than the sample would indicate; probably about 2 or 3 percent of zinc and about 1 percent of lead.

A chip sample was taken across the most souther ly of the two veins in the 65-foot adit. The sample contained 0.31 percent of zine and 0,89 percent of lead. This sample probably is representative of the average content of the vein.

of the three veins in the north area only the large one cut by the adit is well enough exposed to permit a reasonable estimate of reserves. On the basis of a length of 100 feet, a depth of 100 feet; a width of 7 feet, a conversion factor of 10 cubic feet to a ton, it is estimated that there are about 7,000 tons of material estimated to contain about one-third of a percent of zinc and about one percent of lead with minor amounts of gold and silver.

May, 1944. 


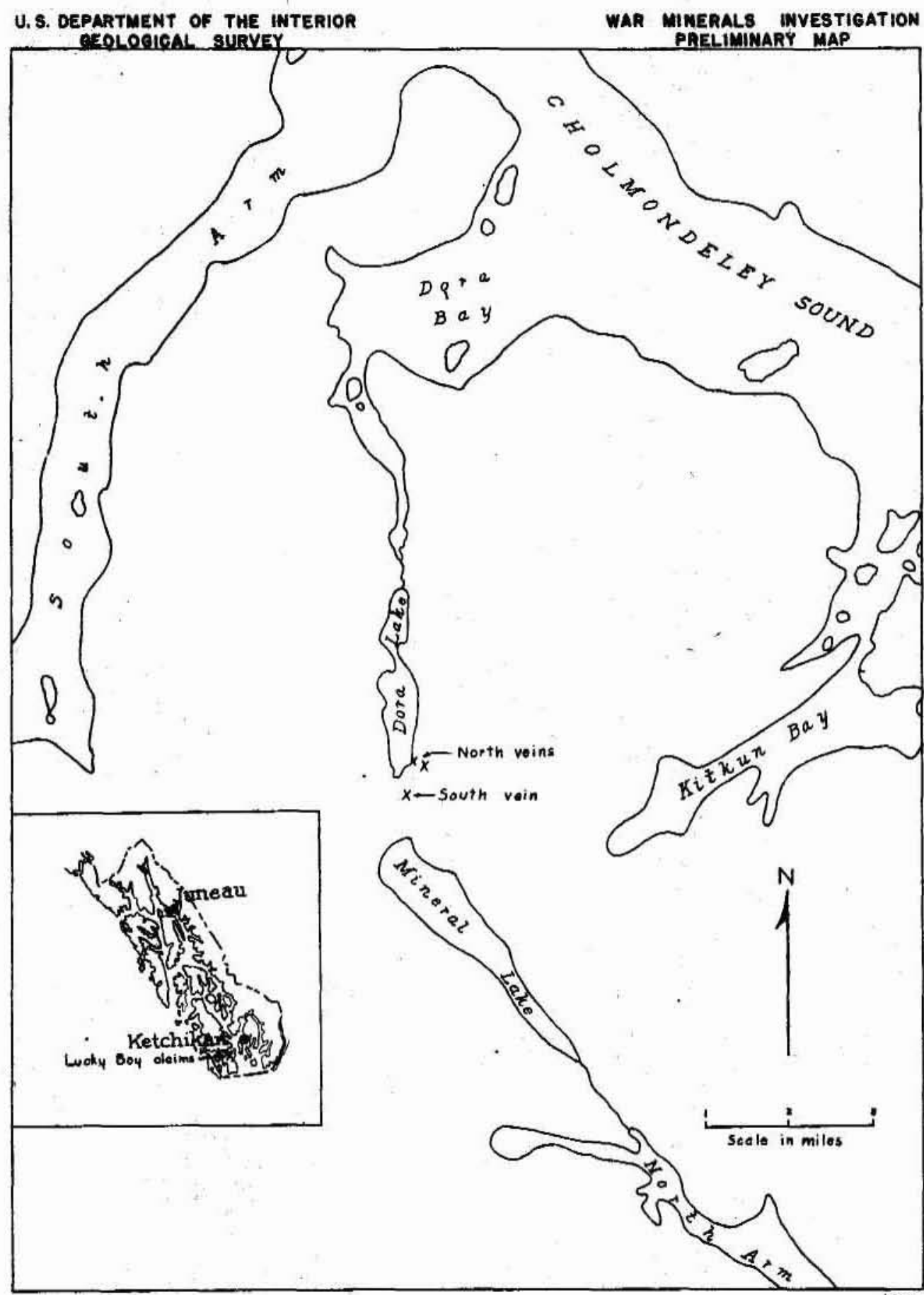

FIGURE I SKETCH MAP SHOWING LOCATION OF LUCKY BOY ZINC DEPOSITS," "2941 Dora Laka, Prince of Waleo Island, southeastern Alaska 


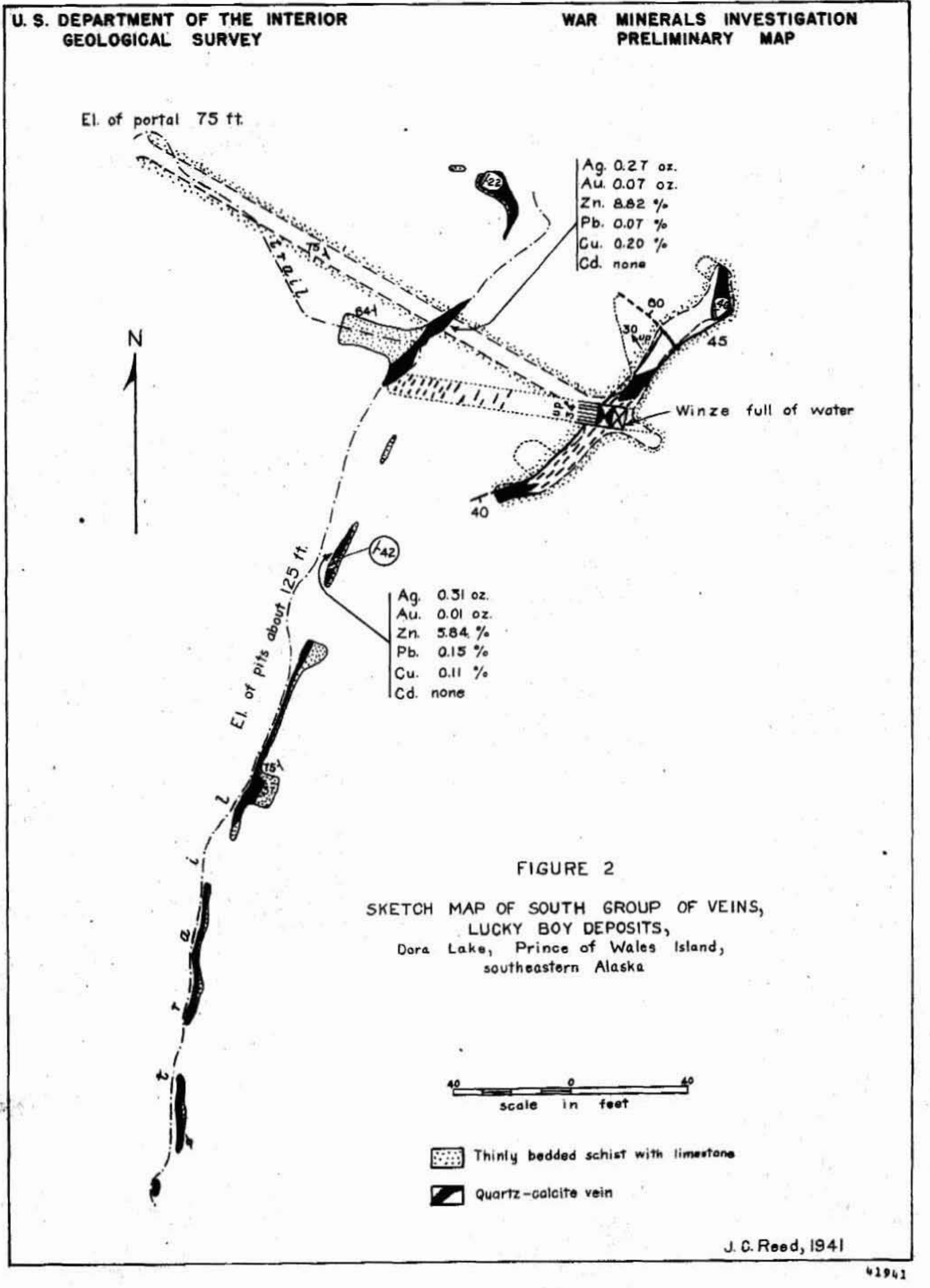




\section{U. S. DEPARTMENT OF THE INTERIOR GEOLOGICAL SURVEY}

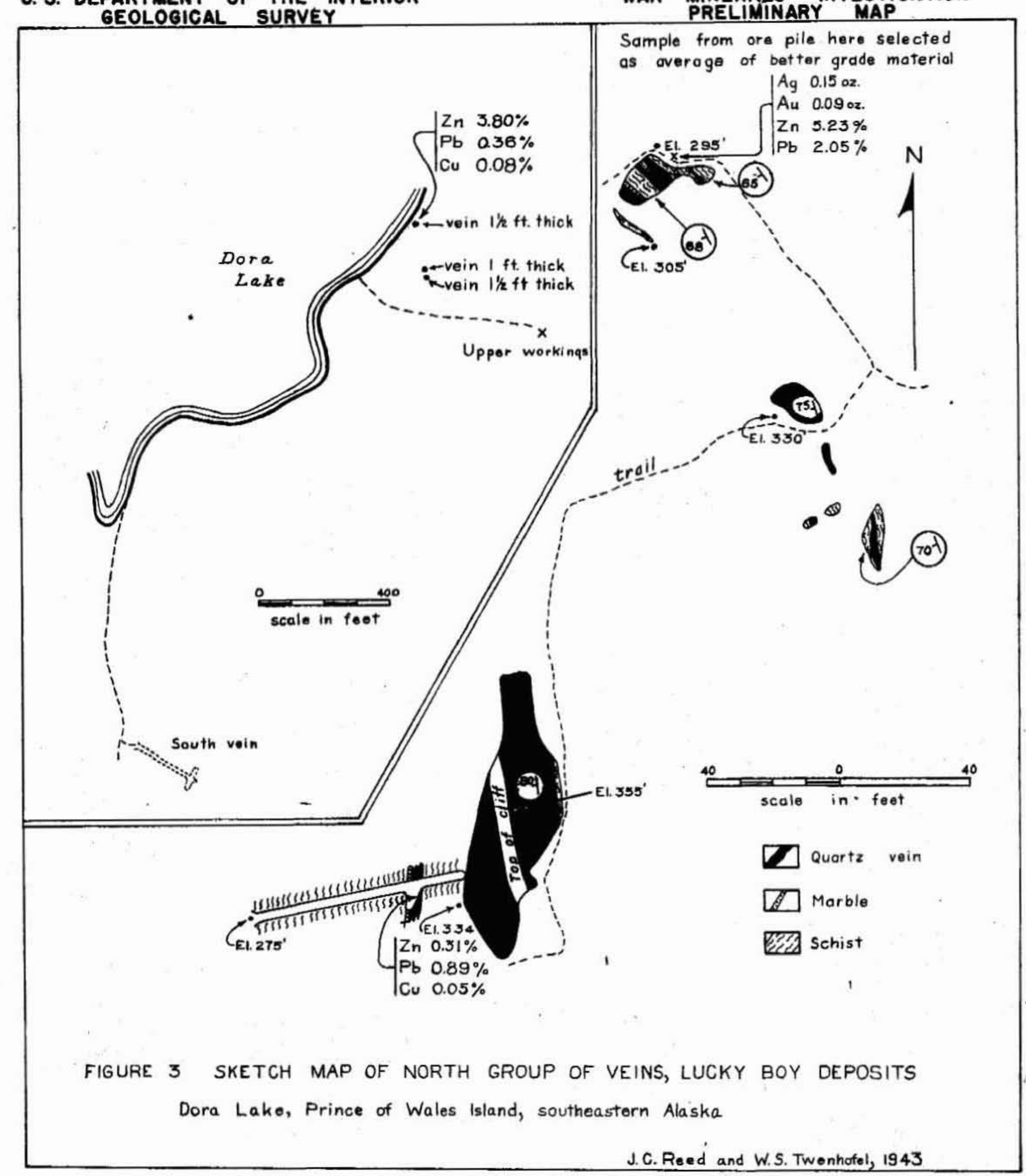

WAR MINERALS INVESTIGATION PRELIMINARY

\section{MAP}

Sample from ore pile here selected 